\title{
Age-related changes in the human primary motor cortex: A macroscopic and microscopic study
}

\author{
Usha K K' Anne George ${ }^{2}$ \\ ${ }^{1}$ Associate Professor, Department of Anatomy, Government Medical College, Thrissur, ${ }^{2}$ Associate Professor, \\ Department of Anatomy, Government Medical College, Kottayam, Kerala, India
}

Background: Cerebral hemisphere has outer gray matter and inner white matter. The cerebrum is folded into gyri and sulci in order to accommodate it in the skull. The thickness of the gray matter varies at sulci and gyri and the mean thickness may be from $1.5 \mathrm{~mm}$ to $4.0 \mathrm{~mm}$. Aims and Objectives: (1) To demonstrate the cells and laminar architecture of the primary motor cortex with different stains. (2) To find out the age-related changes in the thickness of the primary motor cortex and the depth of the central sulcus. Materials and Methods: Cross-sectional study was done using 50 adult human brains and 10 fetal brains obtained from the Department of Forensic medicine and OBG, respectively, in a Government Medical College in Kerala during 2001-2003. At autopsy, the central sulcus and the precentral gyrus were identified. Depth of central sulcus and thickness of precentral gyrus, in upper, middle, and lower parts were measured using Vernier calipers. Tissue specimens were taken from the precentral gyrus and after fixation in $10 \%$ formalin, hematoxylin, and eosin-stained slides were prepared and viewed under a light microscope identifying six laminae. Using an oculo micrometer, width of the six laminae were measured. Pyramidal cells and stellate cells were observed and their size measured. Results: Depth of the central sulcus was more on the right side but it was minimal on the middle part of both sides. The thickness of the precentral gyrus varied from 1 to $6 \mathrm{~mm}$. Maximum thickness of $6 \mathrm{~mm}$ was found in the middle and lower parts in the 21-30 age group. Lamina 5 was the widest of all laminae. Maximum width of $1000 \mu$ was noted in the 41-50 age group. Conclusion: Grey matter thickness of 1-6 mm noted in this study was comparable with other studies. Pyramidal cells of varying sizes were seen in all sections with different staining methods. It was confirmed that neuronal loss is inevitable as age advances.

Key words: Gray matter; Central sulcus; Precentral gyrus; Laminae; Pyramidal cells; Stellate cells
Access this article online

Website:

http://nepjol.info/index.php/AJMS DOI: 10.3126/ajms.v12i11.37798

E-ISSN: 2091-0576

P-ISSN: $2467-9100$

Copyright (c) 2021 Asian Journal of Medical Sciences

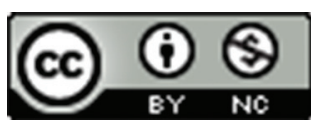

This work is licensed under a Creative Commons Attribution-NonCommercial 4.0 International License.

\section{INTRODUCTION}

The cerebral hemisphere or telencephalon is the broadest part of the forebrain. It has outer grey matter or cerebral cortex and inner white matter. The distinction between cerebral cortex and white matter was first described by Archangelo Piccolomini. He referred to the cerebral cortex as the cerebrum and to the white matter as the medulla. ${ }^{1}$ It was noted that the total surface area of the grey matter or cerebral cortex is about $4000 \mathrm{sq} . \mathrm{cm}$. In order to accommodate it in the limited space within the rigid cranial box, the cerebrum was folded into numerous gyri or convolutions separated by sulci or fissures. About a third of the cerebral cortex was exposed as gyri and the remaining hidden as sulci. ${ }^{2}$ The thickness of the grey matter varies at sulci and gyri and the mean thickness may be from $1.5 \mathrm{~cm}$ to $4.0 \mathrm{~cm}^{3}$

Microscopically the cerebral cortex comprised six layers with different types of neurons varying in their numbers. ${ }^{4}$ The most abundant cells in the cerebral cortex were the 
pyramidal cells. These cells constituted $66 \%$ of the cells in the cerebral cortex irrespective of sensory and motor areas. ${ }^{5}$

Based on the structure and function, the cerebral cortex has many functional areas. The motor areas are cortical areas which on stimulation produce movements of the body. Area 4 or primary motor cortex is situated in the precentral gyrus, on the superolateral surface and it extends into the medial surface of the hemisphere involving the anterior part of the paracentral lobule. ${ }^{2}$ The functional characteristics were made clear when Schott charted out the motor and sensory homunculus by conducting electrical stimulation studies in epileptic patients. ${ }^{6}$

\section{Aims and objectives}

Age-related change in the cerebral cortex has been an interesting topic for many neuro researchers since the beginning of the $20^{\text {th }}$ century. One remarkable work was by Brody who stated that neuronal loss occurred throughout life with more than $50 \%$ cell loss in many cortical areas. ${ }^{7}$ It was noted that like other cells, neurons of the cerebral cortex showed typical senile plaques in old age with degenerating neurites and amyloid bodies. ${ }^{8}$ These types of age changes mainly affect the cholinergic neurons especially in the subcortical gray matter like the basal nuclei. ${ }^{9}$

The objectives of this study were (1) to demonstrate the cells and laminar architecture of the primary motor cortex with different stains. (2) to find out the age-related changes in the thickness of the primary motor cortex and depth of the central sulcus.

\section{MATERIALS AND METHODS}

This cross-sectional study was done at the Department of Anatomy at a Government Medical College in Kerala during 2001-2003. After getting informed consent from relatives of the deceased, fifty brain samples were collected from 11 to 75 years age group irrespective of sex, from the Department of Forensic Medicine. Grossly malformed brain or cases of cerebral hemorrhage were excluded from the study. Ten fetal specimens were collected from the Department of OBG. In the autopsy room, the meninges were stripped off; sulci and gyri were examined. The central sulcus was identified and its depth was measured in upper, middle, and lower parts. Precentral gyrus was identified and tissue specimens were taken from its upper, middle, and lower parts and put into three different labeled bottles which contained $10 \%$ formalin as fixative. After a week of fixation, cortical thickness was measured in the specimens taken from upper, middle, and lower parts using Vernier calipers. The mean value was taken in each age group and compared with other age groups. Slides were prepared and stained with hematoxylin and eosin, carbol thionine, phosphotungstic acid hematoxylin (PTAH), Holzer, Sevier Munger, and congo red stains.

Microscopically, width of each lamina in each age group was measured with an oculo micrometer. The morphological features of cells were studied.

\section{Statistical analysis}

Precentral gyrus was identified and tissue specimens were taken from its upper, middle, and lower parts. After a week of fixation, cortical thickness was measured in the specimens taken from upper, middle and lower parts using Vernier calipers. The mean value was taken in each age group and compared with other age groups. Microscopically, width of each lamina in each age group was measured and tabulated. Statistical analysis was performed using analysis of variance.

\section{RESULTS}

Number of specimens in different age group

A total of 60 specimens were included in the study. The specimens were grouped in age intervals as shown in Table 1.

\section{Depth of central sulcus (Table 2)}

Maximum depth of the central sulcus was on the upper part and the minimum at the middle part of the central sulcus. The measurements were more on the right side compared to the left.

\section{Thickness of precentral gyrus (Figure 1)}

The thickness of the precentral gyrus varied from 1 to $6 \mathrm{~mm}$. In the fetal group, the thickness was equal in the upper, middle, and lower parts. Maximum thickness of $6 \mathrm{~mm}$ was found in the middle and lower regions of the 21-30 age group.

\section{Width of laminae (Table 3)}

There were six laminae in the precentral gyrus.

a) Lamina I (molecular layer) contained only few cells with meshwork of fibers

b) Lamina II (outer granular layer) consisted of stellate

\begin{tabular}{lc}
\multicolumn{2}{l}{ Table 1: Number of specimens } \\
\hline Age group & Number of specimens \\
\hline Fetal & 10 \\
$0-10$ years & 1 \\
$11-20$ years & 4 \\
$21-30$ years & 19 \\
$31-40$ years & 9 \\
$41-50$ years & 8 \\
$51-60$ years & 5 \\
$61-70$ years & 3 \\
$71-80$ years & 1 \\
Total & 60 \\
\hline
\end{tabular}


Table 2: Depth of central sulcus

\begin{tabular}{|c|c|c|c|c|c|c|c|c|}
\hline \multirow[t]{2}{*}{ Age Group } & \multicolumn{4}{|c|}{ Right side (mm) } & \multicolumn{4}{|c|}{ Left side $(\mathrm{mm})$} \\
\hline & Upper & Middle & Lower & Mean & Upper & Middle & Lower & Mean \\
\hline Fetal & 3 & 2 & 3 & 3 & 2 & 1 & 2 & 2 \\
\hline 0-10 years & 4 & 3 & 4 & 5 & 3 & 2 & 3 & 4 \\
\hline $11-20$ years & 24 & 18 & 22 & 21 & 22 & 16 & 20 & 19 \\
\hline $21-30$ years & 16 & 14 & 15 & 15 & 14 & 13 & 14 & 14 \\
\hline $31-40$ years & 19 & 8 & 12 & 13 & 14 & 8 & 11 & 11 \\
\hline $41-50$ years & 16 & 10 & 14 & 13 & 13 & 10 & 12 & 12 \\
\hline $51-60$ years & 14 & 10 & 11 & 12 & 13 & 10 & 10 & 11 \\
\hline $61-70$ years & 20 & 11 & 12 & 14 & 18 & 9 & 11 & 13 \\
\hline $71-80$ years & 24 & 12 & 19 & 18 & 20 & 10 & 15 & 15 \\
\hline
\end{tabular}

\begin{tabular}{lcccccc}
\multicolumn{6}{l}{ Table 3: Width of laminae } \\
\hline $\begin{array}{l}\text { Age group } \\
\text { (years) }\end{array}$ & $\mathbf{I}$ & II & III & IV & V & VI \\
\hline Foetal & 45 & 30 & 80 & 30 & 150 & 60 \\
$0-10$ & 100 & 80 & 150 & 80 & 300 & 80 \\
$11-20$ & 250 & 250 & 500 & 100 & 600 & 300 \\
$21-30$ & 150 & 200 & 600 & 100 & 700 & 400 \\
$31-40$ & 200 & 250 & 600 & 50 & 900 & 400 \\
$41-50$ & 200 & 200 & 500 & - & 1000 & 130 \\
$51-60$ & 110 & 130 & 240 & - & 800 & 100 \\
$61-70$ & 100 & 100 & 200 & - & 600 & 300 \\
$71-80$ & 40 & 60 & 100 & - & 300 & 80 \\
\hline
\end{tabular}

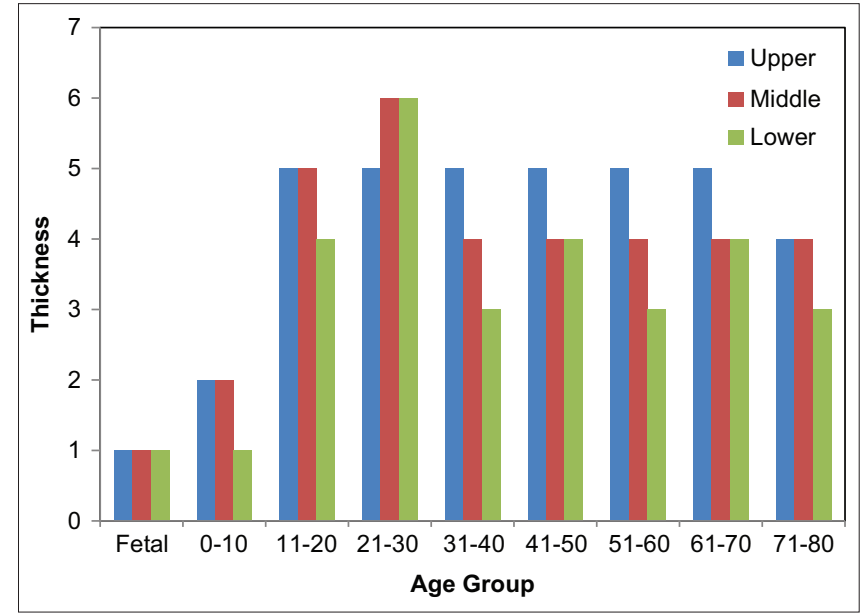

Figure 1: Thickness of precentral gyrus

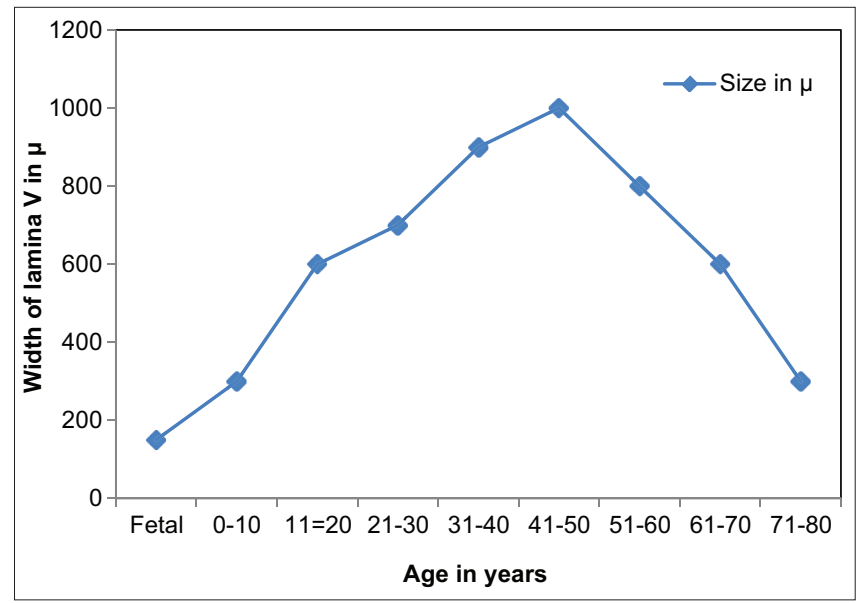

Figure 2: Width of lamina $\mathrm{V}$

of the cell varied from 8 to $64 \mu$. The cells were larger in the deeper laminae.

The cells were grouped into three categories after studying 200 slides for standardization-

1) Small pyramidal cells (SP cells) of size varying from 8 to $20 \mu$.

2) Medium-sized pyramidal cells (MP cells) of size ranging from 21 to $40 \mu$.

3) Giant pyramidal cells (GP cells) of size $41-60 \mu$. 


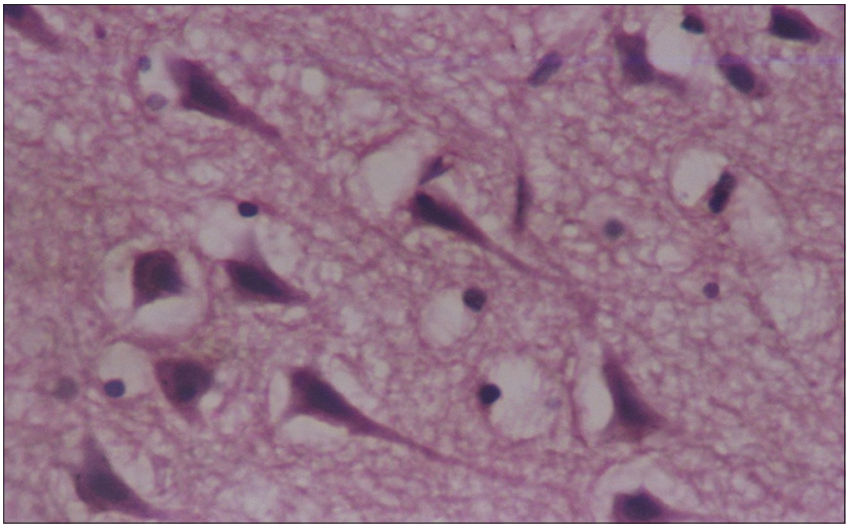

Figure 3: Giant pyramidal cells (H \& E Stain ×200)

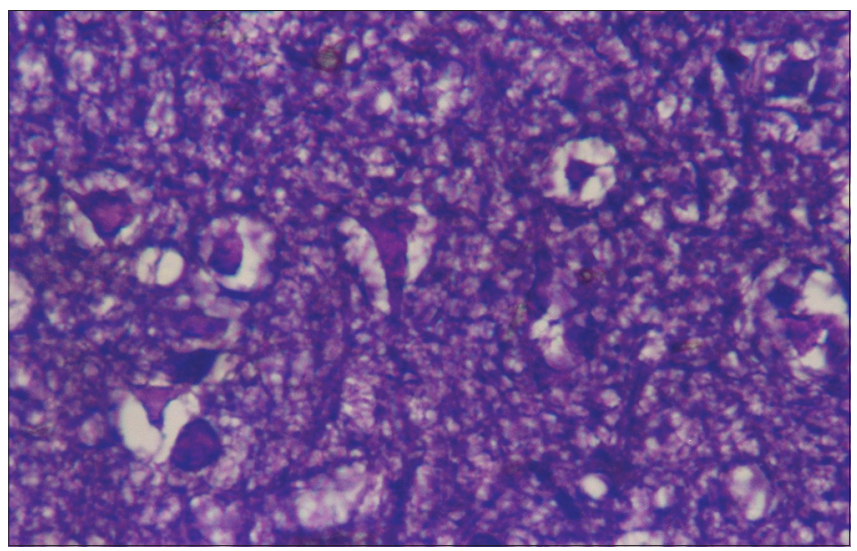

Figure 4: Giant pyramidal cells (Holzer stain $\times 200$ )

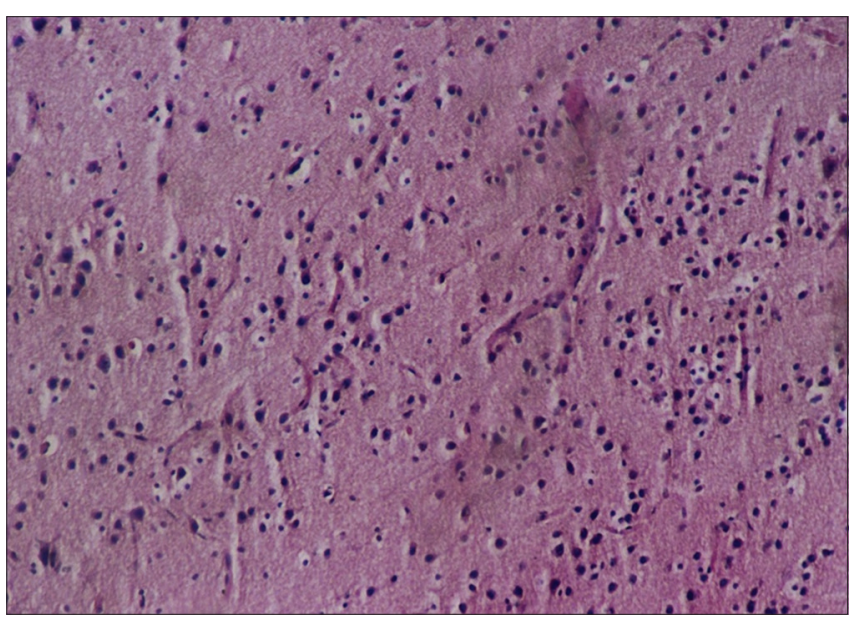

Figure 5: Fetal motor cortex $(\times 100)$

Lamina II and III were occupied by small pyramidal cells. The deeper part of lamina III and IV contained MP cells. GP cells were seen in lamina V. It was noted that pyramidal cells were less in fetal sections. With carbol thionine stain, Nissl granules were seen in the cytoplasm. Even in routine hematoxylin and eosin preparation, Nissl granules could be identified in the slides of the older age group. With phosphotungstic acid hematoxylin stain, neurons had deep

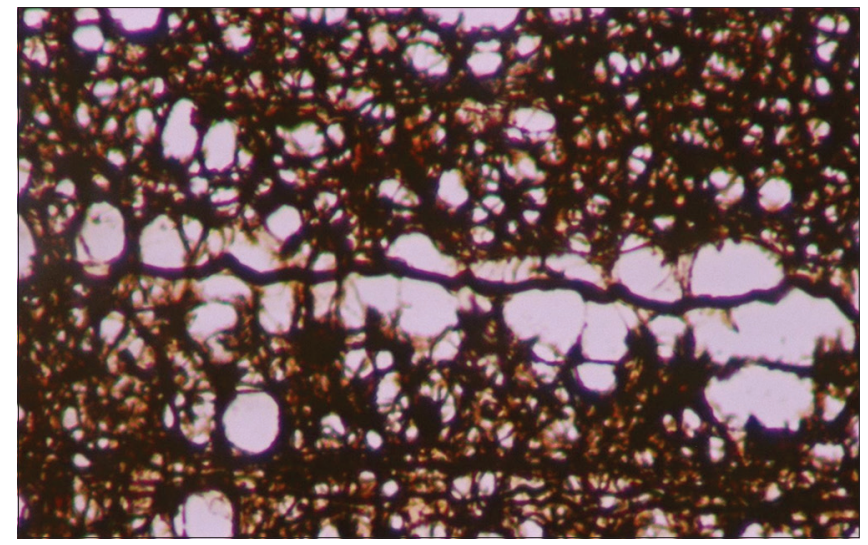

Figure 6: Myelinated fibers (Sevier-Munger stain ×100)

colored nucleus. In the Sevier-Munger staining method, the neurons were seen in golden brown and the nucleus appeared darker.

\section{Stellate cells}

These cells were small and rounded with size varying from 4 to $10 \mu$. These cells were more in Lamina II and hence the lamina was termed as the outer granular layer. Lamina IV or inner granular layer contained less number of stellate cells. Subtypes of non-spiny stellate cells could not be distinguished (Figure 6).

\section{Fibers}

The nerve fibers were present in all laminae, but they were well seen in cell-sparse laminae. With PTAH stain, vertically running fibers were seen in lamina IV, and transversely running inner band of Baillarger were seen in lamina V. With Sevier-Munger stain, the fibers were seen in black color.

\section{DISCUSSION}

The central sulcus is an example of a limiting sulcus which divides the two different functional areas the primary motor area and primary sensory area. ${ }^{10}$ Developmentally, the central sulcus was formed by two parts; upper and lower which coalesce shortly. Therefore, the depth of the central sulcus would be less in the middle part. ${ }^{2}$ The surface area and depth of the central sulcus from MRI and proved that the depth of the middle part of the central sulcus was small relative to adjacent dorsal and ventral regions in humans and great apes. ${ }^{11}$ In the present study, the depth of the central sulcus was less in the middle part. There was a significant difference in depth between the right and left hemispheres and it was more on the right side.

The cortical surface area was studied by many researchers using MRI images. A study measuring cortical thickness 
from MRI, average thickness of the cortex was $2.7-3.2 \mathrm{~mm}$ and it was then compared with a postmortem study. ${ }^{12}$ Postmortem study of Alzheimer's disease showed that loss of white matter was concomitant with normal aging, but the significant reduction in cortical volume was noted in medial temporal gyrus. ${ }^{13}$ In another study using SurfaceBased Approach with MRI showed corresponding age effects in lateral prefrontal and orbitofrontal cortices, precentral gyrus, postcentral gyrus and fusiform gyrus, and no age difference were observed in the anterior cingulate gyrus and visual cortex. ${ }^{14}$ In the present study, the thickness of grey matter varied from 1 to $6 \mathrm{~mm}$. It was more on the summit of the gyrus and less in the sulcus.

There were regional variations in the cytoarchitectonic arrangement of the typical six-layered cerebral cortex. Accordingly, precentral gyrus could be considered as agranular cortex..$^{15}$ In the present study, width of lamina 4 was very minimal with increased thickness of lamina III and V.

Previous studies classified the pyramidal cells based on their morphology, laminar location, and connectivity. Small pyramidal cells in lamina II and III have restricted dendritic tree while medium to large pyramidal cells in the deep layer of lamina III and in lamina V has much more extensive dendritic trees. ${ }^{16}$ During aging, pyramidal cells lose their dendritic spines. ${ }^{17}$

In the present study, the pyramidal cells were either oval or triangular in shape. Size of pyramidal cells varied from 8 to $74 \mu$. Vesicular nucleus and nucleolus could be demonstrated in high magnification. It was noticed that pyramidal cells were less in fetal sections. The three categories of pyramidal neurons SP cells $(8-20 \mu)$ in lamina II and the superficial part of lamina III, MP cells $(21-40 \mu)$ in the deeper part of lamina III and lamina IV and GP cells $(41-74 \mu)$ in the deeper part of lamina $V$ were present.

\section{Limitations of the study}

Since the study was microscopic with available infrastructure, the measurements of laminae and counting of neurons might not be as accurate as those obtained by radiological investigations.

\section{CONCLUSION}

This postmortem study on the human primary motor cortex showed that depth was minimal in the middle part of the central sulcus. The thickness of gray matter varied from 1 to $6 \mathrm{~mm}$ which was comparable with other studies. The six laminar patterns of the cortex were noticed in all sections with different staining methods. Pyramidal cells were the most abundant cells. It was confirmed that neuronal loss occurred along with age advancement.

\section{REFERENCES}

1. Filey C. Behavioural Neurology of White Matter. $2^{\text {nd }}$ ed. Oxford: Oxford University Press; 2012. p. 6.

2. Datta AK. Essentials of Neuro Anatomy. $4^{\text {th }}$ ed. West Bengal: Current Books International; 2015. p. 42-43.

3. Copenhaver WM, Kelly DE and Wood RL. Bailey's Textbook of Histology. $7^{\text {th }}$ ed. William and Wilkins; 1978. p. 354.

4. Grzybowski A and Pietrzak K. Robert Remak (1815-1865). J Neurol. 2013;260(6):1696-1697. https://doi.org/10.1007/s00415-012-6761-6

5. Rockel AJ, Hiorns RW and Powell TP. The basic uniformity in structure of the neocortex. Brain. 1980;103(2):221-244. https://doi.org/10.1093/brain/103.2.221

6. Schott GD. Penfield's homunculus: A note on cerebral cartography. J Neurol Neurosurg Psychiatry. 1993;56(4): 329-333.

https://doi.org/10.1136/jnnp.56.4.329

7. Brody H. The aging brain. Acta Neurol Scand Suppl. 1992;137: 40-44.

8. Reuter-Lorenz PA and Lustig C. Brain aging reorganizing discoveries about the aging mind. Curr Opin Neurobiol. 2005;15(2):245-251.

https://doi.org/10.1016/j.conb.2005.03.016

9. Whitehouse PJ, Price DL and Clark AW. Alzheimer's disease evidence for selective loss of cholinergic neurons in nucleus basalis. Ann Neurol. 1981;10(2):122-126.

https://doi.org/10.1002/ana.410100203

10. Caputi F, Spaziante R, de Divitiis E and Nashold BS Jr. Luigi Rolando and his pioneering efforts to relate structure to function in the nervous system. J Neurosurg. 1995;83(5):933-937. https://doi.org/10.3171/jns.1995.83.5.0933

11. Hopkins WD, Coulonand $O$ and Mangin JF. Observerindependent characterization of sulcal landmarks and depth asymmetry in the central sulcus of the chimpanzee brain. Neuroscience. 2010;171(2):554-551.

https://doi.org/10.1016/j.neuroscience.2010.07.018

12. Fischl B and Dale AM. Measuring the thickness of the human cerebral cortex from magnetic resonance images. Proc Natl Acad Sci U S A. 2000;97(20):11050-11055. https://doi.org/10.1073/pnas.200033797

13. Double KL, Halliday GM, Kril JJ, Harasty JA, Cullen K, Brooks WS, et al. Topography of brain atrophy during normal aging and Alzheimer's disease. Neurobiol Aging. 1996;17(4):513-521. https://doi.org/10.1016/0197-4580(96)00005-x

14. Fjell AM, Westlye LT, Amlien I, Espeseth T, Reinvang I, Raz N, et al. High consistency of regional cortical thinning in aging across multiple samples. Cereb Cortex. 2009;19(9):20012012.

https://doi.org/10.1093/cercor/bhn232

15. Galaburda AM and Kemper TL. Cytoarchitectonic abnormalities in developmental dyslexia: A case study. Ann Neurol. 1979;6(2):94-100. 
https://doi.org/10.1002/ana.410060203

16. Feldman $\mathrm{ML}$ and Dowd C. Loss of dendritic spines in aging cerebral cortex. Anat Embryol (Berl). 1975;148(3):279-301. https://doi.org/10.1007/bf00319848

17. Jones EG and Peters A. Cellular Components of Cerebral Cortex. Vol. 1. New York: Meeting Press; 1984. p. 521-553.

Authors Contribution:

UKK - Concept and design of the study, review of literature, collection of specimen and identification of areas of brain, preparation of slides using $\mathrm{H} \& \mathrm{E}$ stain, categorizing slides, identifying different layers, cells, measurements, data analysis, interpretation, statistics and preparation of manuscript; AG - Review of literature, data analysis, interpretation, statistics and revision of manuscript.

Work attributed to:

Department of Anatomy, Government Medical College, Kottayam, Kerala, India.

Orcid ID:

Dr. Anne George - (i) https://orcid.org/0000-0001-8055-4529

Dr. Usha K K - (i) https://orcid.org/0000-0002-5116-5273

Source of Support: Nil, Conflict of Interest: None declared. 